\title{
Effects of salinity on specific gravity and viability of eggs of a North American minnow (Cyprinidae)
}

\author{
DAVID E. COWLEY ${ }^{1}$, JANELLE C. ALLEMAN ${ }^{1}$, ROSSANA SALLENAVE ${ }^{1,2}$, \\ RYAN R. MCSHANE ${ }^{1,3}$ and PATRICK D. SHIREY ${ }^{1,4}$ \\ ${ }^{1}$ Department of Fish, Wildlife, and Conservation Ecology, New Mexico State University, P.O. Box 30003, MSC 4901, \\ Las Cruces, New Mexico 88003. E-mail: dcowley@nmsu.edu \\ ${ }^{2}$ Department of Extension Animal Sciences and Natural Resources, New Mexico State University, Las Cruces, \\ New Mexico. \\ ${ }^{3}$ Present address: Department of Biology, Colorado State University, Fort Collins, Colorado. \\ ${ }^{4}$ Present address: Department of Biological Sciences, University of Notre Dame, Notre Dame, Indiana.
}

\begin{abstract}
SUMMARY: The influence of salinity on survival, specific gravity, and size of eggs of the endangered Hybognathus amarus (Rio Grande silvery minnow) was studied to provide insight into factors affecting their potential dispersal and fate. Under low salinity conditions egg specific gravity declined significantly in the first hour after spawning as the perivitelline space of the egg filled with water. Egg specific gravity achieved a minimum value approximately $1 \mathrm{~h}$ post-spawning and remained approximately constant until hatching, which occurred near $48 \mathrm{~h}$ post-spawning at $20^{\circ} \mathrm{C}$. Specific gravity of the egg depended on the salinity of the water surrounding the egg: hardened eggs changed rapidly in diameter and specific gravity when exposed to water of higher salinity. Size and specific gravity of $H$. amarus eggs also differed when the eggs were incubated in different groundwater sources. Experiments indicated that calcium chloride saline solution had a greater effect on egg specific gravity and size than did solutions of sodium or potassium chlorides. Survival of $H$. amarus eggs declined sharply at salinity greater than 3 (practical salinity units, PSU) and was only $5 \%$ at a salinity of 8 . Habitat restoration to benefit $H$. amarus should consider the salinity of habitats in which eggs incubate.
\end{abstract}

Keywords: fish egg drift, buoyancy, osmosis, survival, Hybognathus amarus.

RESUMEN: EFECTOS DE LA SALINIDAD SOBRE LA GRAVEDAD ESPECÍFICA Y LA VIABILIDAD DE HUEVOS DE UNA CARPA NORTEAMERICANA (CIPRINIDAE). - El efecto de la salinidad sobre la supervivencia, gravedad específica y talla de los huevos del ciprínido puesto en peligro de extinción, Hybognathus amarus, fue estudiado para proporcionar información sobre los factores que afectan la dispersión y el destino de los huevos. Bajo condiciones de salinidad baja la gravedad específica del huevo disminuyó de forma significativa durante la primera hora después de la puesta, a medida que el espacio del perivitelino del huevo se fue llenando de agua. La gravedad específica del huevo alcanzó un valor mínimo 1 hora después de la puesta y quedó aproximadamente constante hasta eclosión, que ocurrió alrededor de 48 horas tras la puesta a $20^{\circ} \mathrm{C}$. La gravedad específica del huevo dependió de la salinidad del agua que le rodeaba. Los huevos con corion endurecido cambiaron rápidamente en diámetro y gravedad específica cuando fueron expuestos a agua de salinidad más alta. El tamaño y la gravedad específica de los huevos de H. amarus también se diferenciaron cuando los huevos fueron incubados en diferentes fuentes de agua subterránea. Los experimentos indicaron que la solución salina del cloruro de calcio tuvo un mayor efecto sobre la gravedad específica del huevo que las soluciones de los cloruros del sodio o del potasio. Expuestos a soluciones de salinidad de más de 3 (PSU), la supervivencia de los huevos de H. amarus disminuyó claramente, bajando a sólo el $5 \%$ en la solución de 8 . La restauración del hábitat con el objetivo de beneficiar a H. amarus debe considerar la salinidad de los hábitats en los cuales el huevo incuba.

Palabras clave: deriva de huevos de peces, flotabilidad, ósmosis, supervivencia, Hybognathus amarus. 


\section{INTRODUCTION}

The passive dispersal of fish eggs in the aquatic environment is an interesting phenomenon and one well-studied in the marine realm, where understanding factors affecting population size, age structure, and spatial extent has particular relevance to designing effective reserves or establishing regional fishing quotas. An extensive literature exists for commercially valued species regarding depths at which eggs drift in ocean currents and the spatial occurrences of larvae over time. Although many freshwater species produce similar semi-buoyant eggs that can be dispersed as easily as those in the marine environment, there are fewer studies focused on the pelagic eggs of fishes in fresh waters. Little is known about the physical properties of eggs of many freshwater fish species, especially how displacement of eggs from one location to another affects their survival. Variation in early life survival is important to long-term population features such as effective population size (Cowley, 2008), the ratio of effective size to census size (Turner et al., 2006), and the overall level of genetic variation for adaptability, which can be depleted with extreme variation in egg survival (Hedgecock, 1994; Turner et al., 2006). This is especially important for a number of North American minnow species, such as the endangered Hybognathus amarus (Cyprinidae: Rio Grande silvery minnow), which have undergone extensive range reductions and have been largely extirpated from their historic ranges due to dam construction and related water development projects (Cowley, 2003, 2006; Dudley and Platania, 2007). This paper examines the physical properties of eggs of $H$. amarus, which is considered to be a member of the pelagophil reproductive guild (Balon, 1975; Platania and Altenbach, 1998).

Minnows producing semi-buoyant pelagic eggs are widespread in rivers of North America, and $H$. amarus is representative of a host of North American freshwater fishes and other notable marine and anadromous species such as Morone saxatilis (striped bass). These species produce non-adhesive semi-buoyant eggs that have long been known to drift in river currents, and they are easily collected with simple window screen-like devices (Moore, 1944). Properties of $H$. amarus eggs are also potentially informative for the other six members of the Hybognathus genus that are similarly imperiled in parts of their historic ranges, such as $H$. nuchalis (Mississippi silvery minnow) and H. hayi (cypress minnow). The $H$. amarus broadcast spawns nonadhesive, semi-buoyant eggs that can drift downstream as they develop (Platania and Altenbach, 1998). Spawning appears to be initiated by elevated river discharge, but literature is lacking on species preferences for spawning habitats. Larval and young-of-year $H$. amarus are known to be associated with vegetation in low velocity floodplain habitats following sufficiently high river discharge (Cowley, unpublished data).

Transport of semi-buoyant fish eggs by water currents is assisted by the perivitelline space of the egg, which swells with water shortly after spawning and increases the size of the egg while decreasing its specific gravity. Although fecundity data are presently unavailable in the literature for $H$. amarus, members of the genus Hybognathus are known to have high reproductive potential and a life span long enough to persist through drought periods of several years (Cowley et al., 2006). The species is also a strong swimmer (Bestgen et al., 2003) with a robust body shape (Cowley et al., 2006). Together these life history features were probably important factors in the species' once widespread distribution in the Rio Grande because they facilitate bidirectional dispersal. Government-sponsored recovery for Hybognathus minnows provides a purpose to pursue river restoration (Cowley, 2006), but substantial ecological knowledge is needed to determine which aspects of habitat restoration would best favor recovery of species like H. amarus (Cowley et al., 2006).

Because fish eggs can drift downstream, it is important to understand how the environmental conditions of habitats in which eggs may incubate might affect their relative survival or viability fitness. There is wide variation in different river systems in terms of dissolved substances, salinity gradients, sediment load, and other abiotic environmental factors. Studies of $M$. saxatilis eggs suggest that episodic events such as pulses in river flow or strong winds during the spawning season have an important role in regulating fish recruitment (North et al., 2005). However, little is known of the effects of these factors on freshwater fish eggs such as Cyprinid minnows.

The objectives of this paper are to estimate the effects of salinity on egg size and specific gravity (relative density) for H. amarus and to estimate egg survival at increasing levels of salinity. We hypothesize that increased osmotic pressure associated with increased salinity will cause less water to enter the egg and result in smaller, denser eggs at higher salin- 
ity. The final objective of this paper is to link laboratory results with field conditions in the Rio Grande with respect to the potential for eggs to survive in floodplain habitats of varying salinity.

\section{MATERIALS AND METHODS}

\section{Egg collection}

Gravid adult $H$. amarus were obtained from a captive stock held at a facility ("A-Mountain") on the New Mexico State University (NMSU) campus or from a captive stock maintained at the Dexter National Fish Hatchery and Technology Center (Dexter). For each experimental trial three to five gravid females were introduced singly into their respective spawning aquarium along with one or two conspecific males. Early morning spawning in aquaria was initiated by intra-peritoneal injection of carp pituitary extract (CPE, $300 \mu \mathrm{g} \mathrm{ll}^{-1}, 0.1 \mathrm{cc}$ per fish) (Platania and Altenbach, 1998) approximately $12 \mathrm{~h}$ earlier. Eggs were collected from each spawning aquarium as close as possible to spawning. For spawning prior to sunrise, a small headlamp fitted with a red light was used to illuminate the aquarium and a small dip net was used to collect eggs that had not begun to swell with the intake of water into the perivitelline space. Eggs were transferred into treatment aquaria and allowed to develop. At the conclusion of spawning, the adult fish were removed from the aquaria and returned to the captive stock. At the end of each trial, larval $H$. amarus not used in the experimental measurements were collected from the bottom of the treatment aquarium with a flexible siphon tube and returned to the captive rearing facility.

\section{Specific gravity measurements}

Specific gravity of $H$. amarus eggs was measured using a density gradient column (Coombs, 1981). The density gradient column used in our experiments (Techne Inc.) included a filling device so that two solutions of different density could be introduced, filling the column from the bottom with progressively denser solution. Calibrated glass density beads [Techne (Cambridge) Ltd] were used as reference points of known specific gravity. Specific gravities of density beads were $0.9998,1.0009$, $1.0020,1.0031,1.0042,1.0053,1.0064,1.0076$, 1.0086, and 1.0097. Two salt solutions, one consist- ing of deionized water and the other of deionized water plus Instant Ocean ${ }^{\circledR}$ (Aquarium Systems) to yield a salinity of approximately 45 practical salinity units (PSU), were used to establish a linear density gradient in the column. The linear density gradient containing calibrated beads of known density was used to measure the specific gravity of the eggs. The position of the calibrated density beads was recorded immediately before introducing each batch of eggs into the column.

Based on earlier literature, which described egg specific gravity for pelagic-spawning minnows as a static property (e.g. Platania and Altenbach, 1998), it was initially thought that the fish eggs could be placed on the top of the linear density gradient and that they would sink to a position of neutral buoyancy (Coombs, 1981). However, the eggs introduced in this manner fell continuously in the linear density gradient, reaching the bottom of the cylinder after approximately $1 \mathrm{~h}$, giving no clear indication of the specific gravity of the egg. The eggs were visually much smaller in diameter as they sank in the density gradient and some eggs ruptured before reaching the bottom of the density gradient (salinity $>25$ ). Thus, the buoyancy of the egg appeared to be highly dynamic and changed continually as the egg was exposed to increasingly higher salinity in the density gradient column. A novel approach was required to measure the specific gravity of the egg using a density gradient column, which was accomplished by introducing the eggs into the bottom of the density gradient column from which they ascended rapidly to a point of neutral buoyancy.

To measure specific gravity, 10 to 20 eggs were expelled with a small amount of water into the lower one-quarter of the density column from a glass tube attached to a thumb-wheeled pipetter. Integrity of the density gradient was maintained by carefully inserting the glass tube along the inner surface of the density gradient column taking care not to disturb the calibrated glass beads. Using this technique, the eggs rose rapidly in the density column to their point of neutral density where they remained for several min, after which the eggs began to fall in the density gradient column. The position of neutral buoyancy of each egg in the column was recorded according to reference marks on the glass column. These measurements were converted to specific gravity using the regression of specific gravity of the reference beads on their vertical position within the density gradient column. This procedure was repeated for 
every batch of eggs subjected to specific gravity measurement.

Up to 50 eggs could be introduced before the linearity of the density gradient was destroyed. After inserting each batch of eggs, the position of the calibrated density beads was recorded and evaluated visually for linearity. A new density gradient was established when departures from linearity in the density gradient were apparent, most obviously in the positions of the outer density beads relative to those of intermediate specific gravity.

\section{Effects of salinity on egg survival}

To determine the effects of salinity on $H$. amarus egg survival, batches of 20 to 30 eggs were incubated for $48 \mathrm{~h}$ in salinities ranging from 1 to 8 . Salinity treatments were prepared by adding a known amount of Instant Ocean ${ }^{\circledR}$ to deionized water to yield the desired level of salinity. The experiment was repeated nine times with each replicate using eggs produced from a different female. Salinity levels were chosen that encompassed values measured in the Rio Grande and Pecos River (New Mexico Environment Department, Surface Water Quality Bureau, unpublished data) because the latter has been considered for reintroduction of $H$. amarus. The treatment chambers consisted of seven 11 glass jars filled with water of a specific salinity into which compressed air was introduced with an air stone. Egg viability (survival rate) was represented by the proportion of live embryos after $48 \mathrm{~h}$ of incubation.

\section{Egg specific gravity from spawning to hatching}

To determine if egg buoyancy varied with developmental age, specific gravity of eggs was measured at 10, 45 and $60 \mathrm{~min}$ post-spawning and at approximately $12 \mathrm{~h}$ increments until just prior to hatching near 48 h post-spawning. Egg specific gravity was measured at each development age in one to four trials, with each trial ranging from 8 to 34 eggs. The specific gravity of newly fertilized eggs prior to swelling could not be measured because these eggs were well below the densest reference bead (1.0097) in the density gradient column.

The data were analyzed using analysis of variance of a hierarchical fixed effects model with experimental trial nested within developmental age. Analyses were conducted using the GLM procedure of SAS (SAS Institute, Inc., 1989). Least squares means (Goodnight and Harvey, 1978) were used for pair-wise comparisons between developmental ages. Maximum experiment-wise error rate was controlled in the multiple pair-wise comparisons of treatment means by adjusting the nominal significance level $(\alpha=0.05)$ by $\alpha^{\prime}=1-(1-\alpha)^{1 / c}$ (Sidak, 1967), where $c$ was the number of comparisons.

\section{Effects of salinity and sediment on egg specific gravity}

A 2 × 2 factorial experimental design was used to evaluate the combined effects of salinity and suspended sediment on $H$. amarus eggs. Treatment aquaria were of four types: (1) well water, (2) well water with $400 \mathrm{~g}$ of Rio Grande sediment added, (3) well water with salt (Instant Ocean ${ }^{\circledR}$ ) added to yield a salinity of 4, and (4) well water with salt and $400 \mathrm{~g}$ sediment added to give a salinity of approximately 4. Rio Grande sediment was collected approximately $5 \mathrm{~km}$ south of Socorro, New Mexico (U. S. Highway 380 crossing), then air dried, and pulverized to break up small clods of fine sediment. Sediment treatments consisted of glass aquaria containing $25 \mathrm{l}$ of well water to which $400 \mathrm{~g}$ of dried and clod-free river sediment were added and thoroughly mixed. Sediment was retained in suspension with compressed air introduced through a large air stone. The total suspended solids, measured immediately prior to addition of the eggs, was $96.3 \mathrm{mg} \mathrm{l}^{-1} \pm 0.5$. Aquaria with salinity treatments were prepared by adding an amount of Instant Ocean ${ }^{\circledR}$ to well water to yield a desired level of salinity. The salinity of 4 was chosen based on the results of the study on egg survival, which indicated about $50 \%$ mortality at that salinity. All aquaria were aerated and maintained at approximately $20^{\circ} \mathrm{C}$.

A minimum of 40 eggs from each successfully spawned female were collected within minutes of spawning and immediately transferred to on-site temporary enclosures containing treatment water (each treatment received approximately 120 eggs). The eggs were allowed to harden for $6 \mathrm{~h}$ before being moved from the A-Mountain rearing facility to treatment aquaria in our NMSU laboratory containing the same concentration of treatment or well water. After $24 \mathrm{~h}$ of incubation, the specific gravity and egg diameter were measured in random samples of eggs from each treatment aquarium. Twenty eggs per treatment were measured. The remaining eggs were allowed to hatch and larvae were returned to the A- 
Mountain facility. The experiment was repeated six times, each time using eggs from a different female.

Egg diameter measurements were made at $20 x$ magnification using a dissecting microscope fitted with an ocular micrometer. The analysis of variance was carried out using the GLM procedure of SAS (SAS Institute, Inc., 1989). Additional details of the analysis were consistent with the description in the previous section.

\section{Effects of sediment and salinity on egg specific gravity in different waters}

This experiment followed the same general $2 \mathrm{x}$ 2 factorial design as above using two levels each of sediment and salinity, but it was conducted at Dexter in 2005 using H. amarus, with the following differences in treatment conditions. Multiple sets of four treatment aquaria consisting of 12.51 of well water mixed with 12.51 deionized (reverse-osmosis) water and the following additions were prepared: 1) control (no additions, salinity 1.4),2) sediment (400 g pulverized, clod-free Pecos River sediment), 3) salinity (Instant Ocean ${ }^{\circledR}$, final salinity of 5.4), and 4) sediment plus salinity (400 g pulverized river sediment plus Instant Ocean ${ }^{\circledR}$, final salinity of 5.4). Pecos River sediment was collected at the bridge crossing just outside Dexter, New Mexico (N. M. Highway 409 crossing), and then air-dried and pulverized to break up small clods of fine sediment. Each aquarium was fitted with a $30 \mathrm{~cm}$ air stone for aeration and circulation. As spawning occurred, 120 eggs from one female were moved into one set of four treatment aquaria prepared as listed above. Eggs from four females were mixed into one set of four treatment aquaria. Therefore, a single female contributed 120 eggs in total, with 30 eggs allocated to each treatment aquarium. This set-up was replicated four times using eggs from a total of 16 females (Alleman, 2008). Eggs were incubated for $24 \mathrm{~h}$ at $23^{\circ} \mathrm{C}$ with a range of $\pm 2^{\circ} \mathrm{C}$ after which egg measurements were taken. Data analyses were consistent with procedures described in the previous section.

\section{Effects of different salts on egg specific gravity}

This experiment was conducted at NMSU during 2007 using H. amarus eggs. Stock solutions (salinity of 24) of three salts (calcium chloride, potassium chloride, and sodium chloride) were prepared. Six 3.81 jars were prepared by diluting appropriate

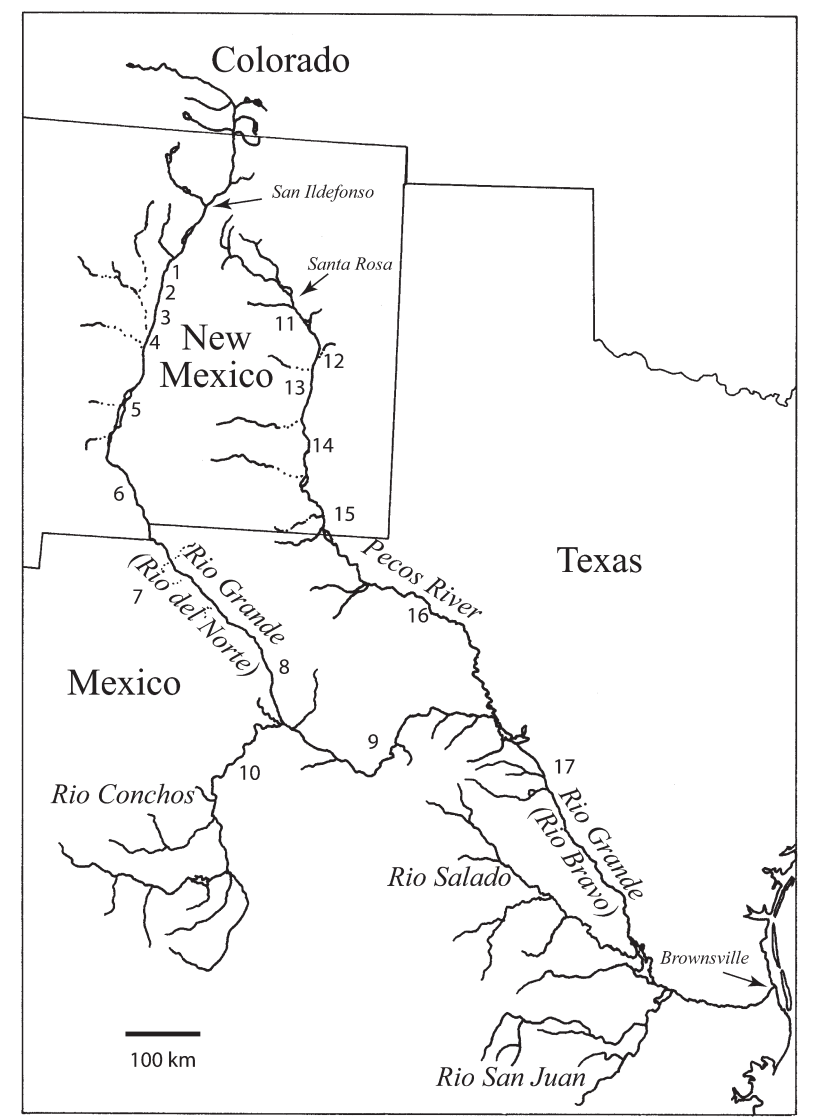

FIG. 1. - The historic range of $H$. amarus was from near San Ildefonso and Santa Rosa on the Rio Grande and Pecos River in north-central New Mexico to the river mouth near Brownsville, Texas. Numerals denote river reaches (Table 2): 1 - Albuquerque, 2 - Belen, 3 - Jarales, 4 - Bernardo, 5 - Elephant Butte Reservoir, 6 - Las Cruces, 7 - El Paso, 8 - Fort Quitman, 9 - Big Bend, 10 - Rio Conchos, 11 - Fort Sumner, 12 - Wagner Ranch, 13 - Bottomless Lakes, 14 - Lake Arthur, 15 - Carlsbad, 16 - Red Bluff, 17 - Amistad Reservoir to Falcon Reservoir.

volumes of stock solution with deionized water to achieve two final salinities of 4 and 8 of each salt. A seventh jar, which provided a control, consisted of deionized water with no salt added. All jars were filled to a volume of 31 and water within the jars was aerated with $2.5 \mathrm{~cm}$ air stones and the jar tops were covered loosely with Parafilm ${ }^{\circledR}$ to minimize evaporation. An equal number of eggs from a single female were transferred into each of the six treatment jars plus a control. Eggs from eight $H$. amarus females were obtained and used in the experiment (Alleman, 2008); thus, all treatments and the control were replicated eight times in the experimental setup with each replicate using eggs from a different female. As close as possible to fifty eggs were transferred into each jar. Egg measurements for specific gravity and diameter were taken after 24 $\mathrm{h}$ of incubation. 


\section{Measurement of Rio Grande floodplain salinity}

During the late spring of 2005, significant snow pack at high elevations in the Rio Grande basin led to an extended period of flooding of lateral habitats along the Rio Grande of central New Mexico. In late May to mid-June, salinity, temperature and dissolved oxygen were measured in the vicinity of Albuquerque, Belen, Jarales, and Bernardo, New Mexico (Fig. 1). Habitats included the main channel of the Rio Grande, inundated floodplains, drain canals, and two irrigation "return canals" that return irrigation water back to the middle Rio Grande. All measurements of salinity were obtained with a YSI 63 meter. Salinities by river reach were compiled from publications (Hem, 1970; Anonymous, 1979; Eaton and Andersen, 1987) and public agency databases (New Mexico Environment Department Surface Water Quality Bureau; EPA STORET data; http://www.epa.gov/storet/).

\section{RESULTS}

\section{Effect of salinity on egg viability}

Egg viability (fitness), measured as the proportion of eggs surviving, declined as the salinity of the incubation water increased (Fig. 2). The proportion of live embryos at $48 \mathrm{~h}$ post-spawning decreased at salinities above 3 , and mortality was $>80 \%$ at salinities of 6 and higher (Fig. 2). Given these results a salinity level of 4 was chosen for subsequent specific gravity experiments using salinity as a treatment.

\section{Egg specific gravity from spawning to hatching}

Specific gravity of $H$. amarus eggs varied significantly between development ages $\left(\mathrm{F}_{4,196}=84.92\right.$, $\mathrm{P}<0.0001$ ) (Fig. 3). Specific gravity declined significantly $(\mathrm{P}<0.0001)$ between 45 min $(\mathrm{N}=8$, mean $=1.0060 \pm 0.0002)$ and $1 \mathrm{~h}(\mathrm{~N}=37$, mean $=1.0034$ $\pm 0.0001)$ post-spawning and between 1 and $12 \mathrm{~h}$ post-spawning $(\mathrm{N}=53$, mean $=1.0028 \pm 0.0001)$. From $12 \mathrm{~h}$ to $48 \mathrm{~h}$ post-spawning, egg specific gravity was not significantly different except at $37 \mathrm{~h}$ post-spawning when the eggs were slightly lower in specific gravity $(\mathrm{P}<0.005)$. Given the relatively constant specific gravity observed from approximately $12 \mathrm{~h}$ post-spawning, subsequent measurements of specific gravity and egg diameter were made at $24 \mathrm{~h}$ post-spawning.

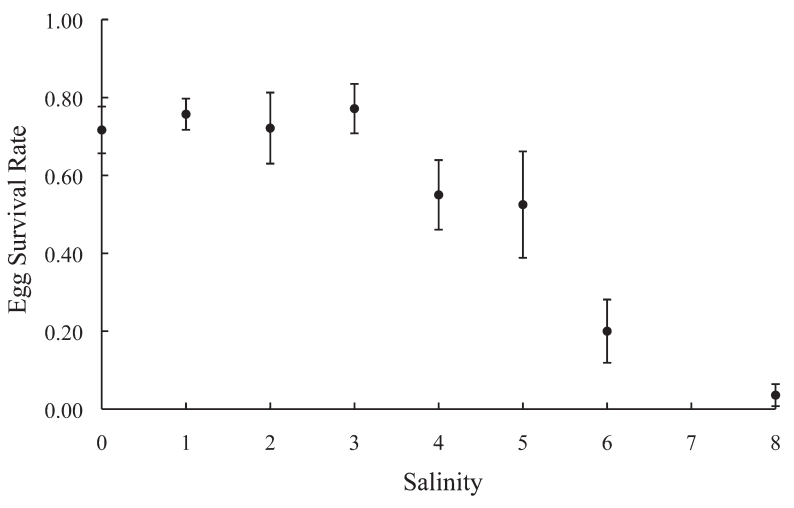

Fig. 2. - Mean survival of $H$. amarus eggs after $48 \mathrm{~h}$ of incubation in solutions of different salinity. Error bars denote plus or minus two standard errors.

\section{Effects of salinity and sediment on egg properties}

Egg specific gravity in our initial experiment at NMSU (Table 1) was significantly altered by suspended sediment $\left(\mathrm{F}_{1,199}=20.81, \mathrm{P}<0.0001\right)$ and salinity $\left(\mathrm{F}_{1.199}=2990.41, \mathrm{P}<0.0001\right)$. There was also a statistically significant interaction between salinity and suspended sediment $\left(\mathrm{F}_{1,199}=34.94, \mathrm{P}<0.001\right)$; the respective effects of sediment and salinity were not additive with respect to the specific gravity of the egg. In general, elevated salinity significantly increased egg specific gravity (Table 1). Whereas the magnitude of change in specific gravity was large with increased salinity, the increase in specific gravity with the addition of suspended sediment was statistically significant but numerically small (Table 1).

Egg diameter (Table 1) was affected significantly by salinity $\left(\mathrm{F}_{1.210}=332.32, \mathrm{P}<0.001\right)$ but not by sediment $(\mathrm{F}=0.48, \mathrm{P}=0.48)$. However, a significant

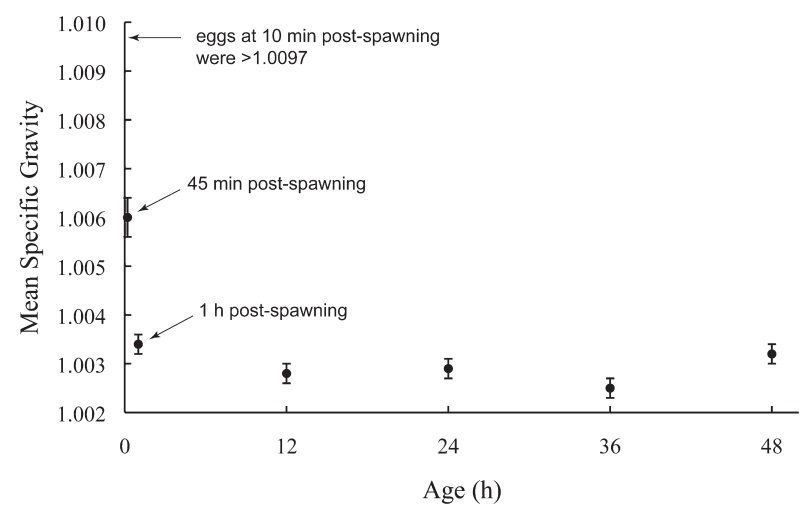

FIG. 3. - Mean specific gravity of $H$. amarus eggs at different post-spawning incubation times. Error bars denote plus or minus two standard errors. Sample sizes: $10 \mathrm{~min}, \mathrm{~N}=8 ; 45 \mathrm{~min}, \mathrm{~N}=8 ; 1 \mathrm{~h}$, $\mathrm{N}=37 ; 12$ h, N=53; 24 h, N=46; 36 h, N=49; 48 h, N=16. 
TABLE 1. - Mean specific gravity and diameter of eggs of $H$. amarus under different incubation conditions and alternate groundwater sources.

\begin{tabular}{|c|c|c|c|c|c|}
\hline \multirow[b]{2}{*}{ Treatment } & \multirow{2}{*}{\multicolumn{2}{|c|}{$\begin{array}{c}\text { Egg Specific Gravity } \\
\text { Mean } \pm \text { SE }\end{array}$}} & \multirow[b]{2}{*}{ Min, Max } & \multicolumn{2}{|c|}{ Egg Diameter (mm) } \\
\hline & & & & $\mathrm{N}$ & Mean \pm SE \\
\hline$-N M S U$ - & & & & & \\
\hline Well Water & 59 & $1.0014 \pm 0.0001$ & $1.0009,1.0028$ & 60 & $3.85 \pm 0.03$ \\
\hline Sediment & 59 & $1.0021 \pm 0.0001$ & $1.0009,1.0036$ & 60 & $3.65 \pm 0.03$ \\
\hline Salinity & 46 & $1.0055 \pm 0.0001$ & $1.0044,1.0081$ & 54 & $3.03 \pm 0.04$ \\
\hline Sediment \& Salinity & 58 & $1.0054 \pm 0.0001$ & $1.0045,1.0080$ & 60 & $3.28 \pm 0.03$ \\
\hline Well Water & 74 & $1.0054 \pm 0.0001$ & $1.0037,1.0082$ & 80 & $2.71 \pm 0.03$ \\
\hline Sediment & 60 & $1.0055 \pm 0.0001$ & $1.0036,1.0075$ & 80 & $2.59 \pm 0.03$ \\
\hline Salinity & 69 & $1.0067 \pm 0.0001$ & $1.0045,1.0084$ & 80 & $2.75 \pm 0.03$ \\
\hline $\begin{array}{l}\text { Sediment \& Salinity } \\
\text { - single salts - }\end{array}$ & 68 & $1.0072 \pm 0.0001$ & $1.0051,1.0088$ & 80 & $2.70 \pm 0.03$ \\
\hline Deionized Water & 71 & $1.0024 \pm 0.0001$ & $0.9986,1.0081$ & 151 & $2.65 \pm 0.02$ \\
\hline $\mathrm{CaCl}_{2}$, salinity 4 & 70 & $1.0060 \pm 0.0001$ & $1.0037,1.0086$ & 158 & $2.30 \pm 0.02$ \\
\hline $\mathrm{NaCl}^{2}$, salinity 4 & 38 & $1.0049 \pm 0.0001$ & $1.0043,1.0055$ & 111 & $2.52 \pm 0.03$ \\
\hline $\mathrm{KCl}$, salinity 4 & 28 & $1.0045 \pm 0.0002$ & $1.0032,1.0052$ & 146 & $2.51 \pm 0.02$ \\
\hline $\mathrm{CaCl}_{2}$, salinity 8 & 55 & $1.0082 \pm 0.0001$ & $1.0055,1.0116$ & 179 & $2.23 \pm 0.02$ \\
\hline $\mathrm{NaCl}^{2}$, salinity 8 & 30 & $1.0072 \pm 0.0002$ & $1.0066,1.0080$ & 98 & $2.35 \pm 0.03$ \\
\hline $\mathrm{KCl}$, salinity 8 & 49 & $1.0068 \pm 0.0001$ & $1.0048,1.0088$ & 153 & $2.46 \pm 0.02$ \\
\hline
\end{tabular}

Table 1 Notes: Egg diameters at $24 \mathrm{~h}$ post-spawning were measured at 20x magnification using a dissecting microscope fitted with an ocular micrometer. Deionized water was produced with a reverse osmosis process.

interaction $\left(\mathrm{F}_{1,210}=45.13, \mathrm{P}<0.001\right)$ was observed between salinity and sediment. Eggs incubated in salinity plus suspended sediment had a greater diameter than eggs incubated in salinity but had a smaller diameter than eggs incubated in suspended sediment alone (Table 1). All of the pair-wise comparisons of mean egg diameter were significant $(\mathrm{P}<0.001)$. A salinity of 4 reduced egg diameter by approximately $22 \%$ relative to the well water control.

Although egg specific gravity increased significantly with salinity $\left(\mathrm{F}_{1,267}=181.33, \mathrm{P}<0.0001\right)$ and sediment $\left(\mathrm{F}_{1,267}=5.56, \mathrm{P}=0.02\right)$ in the trials conducted at Dexter, the specific gravity of eggs in "control" conditions (salinity 1.4) were approximately the same as that observed for eggs under a treatment salinity of 4 at NMSU (Table 1). There was no significant interaction between sediment and salinity $\left(\mathrm{F}_{1,267}=2.28, \mathrm{P}=0.13\right)$. Egg diameter was noticeably smaller at Dexter than at NMSU, but it declined with increased salinity as was observed in the NMSU trials.

\section{Effect of different salts on egg specific gravity}

There was significant variation in egg specific gravity for the different salt treatments $\left(\mathrm{F}_{6,334}=260.2\right.$, $\mathrm{P}<0.0001)$. Of the three salts tested, eggs incubated in calcium chloride solutions of salinities 4 and 8 had significantly higher specific gravity than eggs incubated in the solutions with respective concentrations of sodium or potassium chlorides (Table 1, $\mathrm{P}<0.0001)$. Regardless of the salt solution, egg spe- cific gravity increased with increasing salinity. Eggs were consistently higher in specific gravity for sodium chloride solutions than for potassium chloride solutions, but the differences were only marginally significant $(\mathrm{P}=0.059$ at a salinity of 4 and $\mathrm{P}=0.058$ at a salinity of 8). Egg diameter was reduced most by calcium chloride salinity, followed by sodium chloride salinity, and hardly at all by potassium chloride (Table 1). At a salinity of 8 and relative to egg diameter under control conditions (incubation in deionized water), egg diameter was decreased $16 \%$ by calcium chloride, about $11 \%$ by sodium chloride, and $7 \%$ by potassium chloride.

Egg diameter varied significantly for the different salt treatments $\left(\mathrm{F}_{6.989}=45.61, \mathrm{P}<0.0001\right)$. At a salinity of 4 , both sodium chloride and potassium chloride reduced egg diameters by about $5 \%$ while calcium chloride decreased egg diameter by $11 \%$. In general, egg diameters decreased at higher salinity levels.

\section{Salinity of Rio Grande habitats}

Salinity in the Rio Grande, its floodplain habitats, and adjacent irrigation canals (drainage and return) was measured during a period of high river discharge in late spring of 2005, which coincided with the spawning season of $H$. amarus. Salinities were generally low, in the range of 0.1 to 0.2 (Table 2). However, some floodplain habitats had significantly elevated salinities, most notably in the area near Belen, New Mexico. The extreme values, in 
TABLE 2. - Mean salinity in floodplain habitats in the middle Rio Grande of New Mexico during May to June 2005 compared to selected river reaches of the Rio Grande (see Fig. 1).

\begin{tabular}{|c|c|c|c|}
\hline Location & River Reach & $\mathrm{N}$ & Mean Salinity (range) \\
\hline Floodplain & 2 & 16 & $1.64(0.2-11.2)$ \\
\hline Floodplain & 3 & 15 & $0.18(0.1-0.2)$ \\
\hline Floodplain & 4 & 12 & $0.13(0.1-0.2)$ \\
\hline - comparative values - & & & \\
\hline Drainage Canals ${ }^{\mathrm{a}}$ & $1,2,3,4$ & 13 & $0.54(0.2-0.8)$ \\
\hline Return Canals (Wasteways)a & $1,2,3,4$ & 13 & $0.21(0.2-0.3)$ \\
\hline Rio Grande ${ }^{b}$ & 1 & 12 & $0.3(0.2-0.4)$ \\
\hline Rio Grande ${ }^{\mathrm{a}}$ & 2 & 2 & $0.19(0.17-0.2)$ \\
\hline Rio Grande ${ }^{a}$ & 3 & 4 & $0.13(0.1-0.2)$ \\
\hline Rio Grande ${ }^{a}$ & 4 & 13 & $0.150 .1-0.5)$ \\
\hline Rio Grande ${ }^{b}$ & 4 & 16 & $1.7(0.5-2.8)$ \\
\hline Rio Grande ${ }^{a}$ & 5 & 1 & $0.4(\mathrm{n} / \mathrm{a})$ \\
\hline Rio Grande ${ }^{c}$ & 6 & 2 & $0.35(0.3-0.4)$ \\
\hline Rio Grande ${ }^{\mathrm{d}}$ & 7 & $\mathrm{n} / \mathrm{a}$ & $\mathrm{n} / \mathrm{a}(0.2-2.1)$ \\
\hline Rio Grande ${ }^{\mathrm{d}}$ & 8 & $\mathrm{n} / \mathrm{a}$ & $\mathrm{n} / \mathrm{a}(0.7-5.7)$ \\
\hline Rio Grande ${ }^{\mathrm{d}}$ & 9 & $\mathrm{n} / \mathrm{a}$ & $\mathrm{n} / \mathrm{a}(0.7-0.9)$ \\
\hline Rio Conchos ${ }^{\mathrm{d}}$ & 10 & $\mathrm{n} / \mathrm{a}$ & $\mathrm{n} / \mathrm{a}(0.8-1.2)$ \\
\hline Pecos Rivere,f & 11 & 4 & $1.5(1.2-1.6)$ \\
\hline Pecos River ${ }^{\mathrm{a}, \mathrm{e}, \mathrm{f}}$ & 12 & 2 & $1.45(1.3-1.6)$ \\
\hline Pecos River ${ }^{\mathrm{e}, \mathrm{f}}$ & 13 & 9 & $5.4(2.61-7.7)$ \\
\hline Pecos Rivere,f & 14 & 11 & $4.8(2.4-8.2)$ \\
\hline Pecos River ${ }^{d}$ & 15 & $\mathrm{n} / \mathrm{a}$ & $4.5(0.9-14.1)$ \\
\hline Pecos River ${ }^{\mathrm{d}}$ & 16 & $\mathrm{n} / \mathrm{a}$ & $9.2(6.2-16.2)$ \\
\hline Rio Grande ${ }^{\mathrm{d}}$ & 17 & $\mathrm{n} / \mathrm{a}$ & $\mathrm{n} / \mathrm{a}(0.6-0.7)$ \\
\hline
\end{tabular}

Table 2 Notes: "n/a" denotes not available from sources cited; data sources: ${ }^{\mathrm{C} C o w l e y ~ u n p u b l i s h e d ~ d a t a ; ~}{ }^{\mathrm{b}}$ Anonymous (1979), ${ }^{\mathrm{c}} \mathrm{Hem}(1970),{ }^{\mathrm{d}} \mathrm{Ea}-$ ton and Andersen (1987), ${ }^{\mathrm{e}} \mathrm{New}$ Mexico Department of Game and Fish, ${ }^{\mathrm{f}} \mathrm{EPA}$ STORET database, ${ }^{\mathrm{g}}$ New Mexico Environment Department.

the range of 6.5 to 11.2 salinity, were observed in an area where non-native Tamarix spp. (saltcedar) had been felled, shredded, and left as mulch on the floodplain prior to the high river discharge in 2005. Eleven of the 16 measurements in this area of the middle Rio Grande floodplain were greater than the highest salinity observed in the river and the adjacent irrigation canals.

\section{DISCUSSION}

The results of our experiments showed that the physical properties of $H$. amarus eggs are strongly influenced by salinity of the incubation water and developmental age post-spawning. Moreover, egg size and specific gravity can change if the incubation salinity changes, even after hardening of the egg chorion, as was demonstrated in the density gradient column. The experiments demonstrated a strong negative effect of salinity on egg viability for H. amarus.

Salinity is not often considered a contaminant in water, but significant variations in salinity are common in rivers of arid landscapes where evaporation rates are high (Bailey et al., 2006). Wide ranges in salinity have been reported in the Rio Grande basin (Table 2), especially for river reaches at lower eleva- tions where local variation in geology coupled with temporal variation in drought intensity can yield salinities one-quarter to one-half that of seawater (Eaton and Andersen, 1987). Field measurements along the Rio Grande showed that potentially lethal levels of salinity can exist in inundated floodplain habitats even during high river flows associated with snowmelt. Thus, salinity is likely to be a limiting factor for recovery of the endangered $H$. amarus.

\section{Salinity effects on egg size and specific gravity}

Specific gravity and diameter of $H$. amarus eggs depended on the salinity of the incubation water. An increase in egg specific gravity was accompanied by a decrease in egg diameter. This suggested that the increase in specific gravity of the egg caused by increased salinity was mediated through an osmotic flux of water out of the perivitelline space into the incubation medium, although we cannot rule out an influx of ions into the perivitelline space contributing to the increase in egg specific gravity. The latter seems unlikely because a fish in freshwater is subject to a passive osmotic influx of water and diffusive loss of ions (Varsamos et al., 2005).

Under aquaculture conditions, eggs in different source waters have different sizes and specific gravities (Albrecht, 1964; Gonzal et al., 1987; Spade 
and Bristow, 1999; Molokwu and Okpokwasili, 2002). For instance, problems have been reported in $M$. saxatilis culture regarding eggs floating out of hatching containers when they were incubated in very soft water (Spade and Bristow, 1999). Addition of calcium chloride salt to increase water hardness alleviated the problem, implying that a decrease in egg size or increase in egg specific gravity increases retention of the eggs in the incubation jar.

\section{Egg specific gravity across developmental time}

For H. amarus eggs incubated under control conditions (no salt added), the specific gravity declined significantly and attained an approximate minimum value after $1 \mathrm{~h}$ post-spawning; egg specific gravity was approximately constant from $12 \mathrm{~h}$ to hatching. Gonzal et al. (1987) found that the time to the maximum size of Hypophthalmichthys molitrix (silver carp) eggs was inversely related to water hardness. At high hardness (400-600 $\mathrm{mg} \mathrm{l}^{-1}$ ), the final size was achieved in 3-4 h; in low hardness (100-200 $\left.\mathrm{mg} \mathrm{l}^{-1}\right)$ the final size was achieved in approximately $6 \mathrm{~h}$ (Gonzal et al., 1987). Our results indicated that the temporal duration of swelling of the perivitelline space of the egg was underestimated in previous studies (Platania and Altenbach, 1998). Whereas the previous authors reported that $H$. amarus eggs were fully swollen by about 30 to $45 \mathrm{~min}$ post-spawning, we found a highly significant decrease in specific gravity between one and $13 \mathrm{~h}$ post-spawning. Therefore, their specific gravity value was higher, by an exponent of approximately 4 , than what we observed as the minimal value attained by $12 \mathrm{~h}$ post-spawning. Alderdice (1988) noted that permeability of the zona radiata (chorion) reduced to and remained near a minimum during incubation, which occurred at different times in different species but generally occurred 12 to $24 \mathrm{~h}$ post-spawning.

\section{Physical properties of fish eggs in response to salinity changes}

Contrary to earlier authors, we found the physical properties of $H$. amarus eggs to be highly dynamic, even for hardened eggs. Authors who discuss pelagic eggs in freshwater have generally represented the specific gravity of the egg as a static quantity (e.g. Hardy, 1978; Hurley, 1991; Davin et al., 1999; Dudley and Platania, 1999). Our results clearly indicated that egg specific gravity was highly dynamic in response to the environmental conditions of incubation. This became clear to us in our initial attempts to measure specific gravity of $H$. amarus eggs in the density gradient column. Our experiments also suggest that the specific gravity of pelagic eggs from broadcast-spawning minnow species is likely to vary across geographic regions depending on hydrological conditions and local water chemistry.

\section{Salinity as an agent of selection}

Salinity is a primary water quality factor that exerts selective pressures on fish (Varsamos et al., 2005) and ecological diversification is exhibited among many fish species in response to their relative tolerances to salinity (Higgins and Wilde, 2005; Varsamos et al., 2005; Matthews and Marsh-Matthews, 2006). Our experiments show that a moderate increase in salinity can be expected to negatively affect egg survival, and salinity effects may be exacerbated due to the positive relationship between salinity and egg specific gravity. For example, higher salinities and a corresponding increase in the specific gravity of water may decrease relative egg buoyancy with consequences for transport, retention, and vulnerability to predators.

Our laboratory results showed the potential for intense selection (mediated through mortality) to occur with salinity greater than about 6 . In our experiments, egg mortality for H. amarus was about $50 \%$ at a salinity of $4,80 \%$ at a salinity of 6 , and $95 \%$ at a salinity of 8 . Similar sensitivity to salinity was found for another Cyprinid minnow, Rutilus rutilus (roach), in the northern Baltic Sea (Härmä et al., 2008). Genetic selection might occur under aquaculture conditions and in natural environments. A hyperosmotic medium prevented proper swelling of Clarius gariepinus (African catfish) eggs and caused spinal damage in larvae, and a hyposmotic solution caused eggs to burst from excessive water absorption (Molokwu and Okpokwasili, 2002), suggesting that an optimal salinity (stabilizing selection) may exist for some freshwater species. Elevated levels of calcium ions reduced post-hatch survival of Rhamdia quelen (silver catfish) (Silva et al., 2003) and very low magnesium ion concentrations in water increased mortality of Cyprinus carpio (common carp) eggs (Van der Velden et al., 1991), further indicating that different components of salinity may select for certain genotypes. These avenues of selection may exist in natural habitats as indicated by our finding of 
elevated salinities (salinity $\geq 6$ ) in some Rio Grande floodplain habitats during the spawning season. Clearly, there could be significant concerns about salinity for reproductive success of $H$. amarus in the middle Rio Grande and in other river reaches in the basin that the species formerly occupied (Cowley, 1979; Cowley, 2006). Extreme salinity variations can occur in the Rio Grande with cycles of climatic drought (Eaton and Andersen, 1987).

We observed that a small fraction of eggs survived at a salinity of 8 . The extent to which the species carries genetic variation related to survival in hyperosmotic conditions is presently unknown. Laboratory experiments could be used to evaluate purposeful selection for better survival of the species in elevated salinity. Such experiments would be an efficient method (Falconer and Mackay, 1996) for determining if there is genetic variation available from which to develop better-adapted individuals for release into habitats that are more saline than the middle Rio Grande.

\section{Implications for species recovery and habitat restoration}

The ecology of $H$. amarus eggs is relevant for understanding the current declines in relative abundance of species of freshwater fishes that produce semi-buoyant eggs, which encompasses a diverse group of species that have widely become extinct, extirpated, or highly restricted in distribution. Members of the pelagophil and lithopelagophil reproductive guilds, once widely distributed in larger sand-bed creeks and rivers flowing through arid to semi-arid lands in the United States, are negatively affected by dams, river flow regulation, and levees that reduce the frequency and magnitude of seasonally elevated river discharge and the availability of inundated floodplain habitats (Bestgen and Platania, 1991; Edwards and Contreras-Balderas, 1991; Winston et al., 1991; Bonner and Wilde, 2000; Welker and Scarnecchia, 2004; Cowley, 2006). Pelagophils are thought to spawn independently of the river substrate, to produce numerous buoyant eggs, and to lack or have poorly developed embryonic respiratory organs (Simon, 1999).

Physical properties of pelagic fish eggs have been used in mathematical model simulations of pelagic egg drift in a river (Yeh and Yeh 1980; North et al., 2005). Studies of pelagic eggs of M. saxatilis indicated that dispersal of eggs into good incubation conditions depends on the interaction of episodic events such as freshwater flows and strong winds (North et al., 2005). Computer models suggested decreased egg transport at higher river flows and with stronger winds. Egg transport was enhanced with lower river flows and higher salinity. Over a 16 year period, mean river flow and number of flow pulses during the spawning season accounted for about $70 \%$ of the variation in juvenile abundance in the upper Chesapeake Bay (North et al., 2005).

Our results show that egg specific gravity and egg diameter are significantly affected by salinity and suspended sediment. Both of these properties of the egg affect its potential to be transported by water currents. Laboratory studies have been used to speculate that $H$. amarus offspring could drift hundreds of kilometers downstream (Dudley and Platania, 1999). However, recent experimental data suggest that drift of pelagic fish eggs may be much shorter (Kehmeier et al., 2004). Our results may help explain the disparity between these two views by refining mathematical models of egg transport with egg specific gravity and diameter values that vary with local salinities. With good mathematical representation of egg drift it might be possible to compare the drift potential in river reaches that differ significantly in their salinity or suspended sediment load or in river reaches subjected to alternative restoration strategies.

Because the recovery of the endangered $\mathrm{H}$. amarus provides a means for restoring the middle Rio Grande in New Mexico, it is important to better understand the ecology of the species. Restoration plans will benefit from studies of early life history, food habits (Shirey, 2004; Shirey et al., 2008), life span (Cowley et al., 2006), fecundity, factors influencing sex determination, environmental signals that cue spawning, and preferred spawning habitats. For example, if $H$. amarus prefers to spawn in the floodplain, then egg specific gravity and size would be more important in determining the likelihood of egg displacement from the floodplain, than in determining the likelihood of entrainment into floodplain habitats. In addition to planning the restoration of the Rio Grande habitat, the U.S. Fish and Wildlife Service could use early life history studies to plan for the release of experimental populations of $H$. amarus into suitable habitats.

Habitat conditions that provide "nursery" areas have been described for some species (e.g. Scott and Nielsen, 1989; Scheidegger and Bain, 1995). But for 
many others, including $H$. amarus, it is unknown where juvenile fish successfully complete their larval development. Presently we lack an understanding of the full range of conditions that entrain drifting $H$. amarus eggs into nursery habitats. We do not know if the conditions that entrain drifting eggs also provide good nursery conditions for the egg and larval stages. It is also unknown if larval $H$. amarus are pelagic and drift freely in the water column, if they are benthic and associated with the river substrate, or if they exhibit diel changes between pelagic and benthic behaviors such as described for Aplodinotus grunniens (freshwater drum) and Dorosoma spp. (shad) (Gallagher and Conner, 1983). For all these alternative larval behaviors, it is important to understand how small differences in timing of reproduction can interact with flood-stage events to displace youngof-year fish downstream (Harvey, 1987) or into lateral floodplain habitats. This is especially important when true flood stage events are rare and elevated river discharge is associated directly with flow regulation to deliver water to users, as is the case in the middle Rio Grande of New Mexico. Clearly, broader knowledge of the reproductive ecology of $H$. amarus is important for optimizing river flow regulation and habitat restoration to recover the species.

\section{ACKNOWLEDGEMENTS}

We acknowledge J. Landye, C. Caldwell, W. Knight, and C. Robertson for advice and assistance on rearing, animal husbandry techniques, and transfer of fish between labs. We thank V. Pritchard for assisting with the ontogenetic study and K. Finkbeiner for field measurements of salinity. Helpful comments and discussions that significantly improved the presentation of results were provided by W. Boeing, C. Caldwell, M. Hatch, C. Ortega-Klett, M. Porter, and two anonymous reviewers. The Middle Rio Grande Endangered Species Collaborative Program, the U.S. Bureau of Reclamation, and the New Mexico Agricultural Experiment Station provided funding for this research.

\section{REFERENCES}

Albrecht, A.B. - 1964. Some observations on factors associated with survival of striped bass eggs and larvae. Calif. Fish Game, 50: $100-113$.

Alderdice, D.F. - 1988. Osmotic and ionic regulation in teleost eggs and larvae. In: W.S. Hoar and D.J. Randall (eds.), Fish physiology, vol 6, The physiology of developing fish, Part A, Eggs and larvae, pp. 163-251. Academic Press, London.

Alleman, J.C. - 2008. Effects of incubation salinity on egg properties from North American cyprinids. M.S. thesis, New Mexico State University, Las Cruces.

Anonymous. - 1979. Water resources data for New Mexico. U.S. Geological Survey Water-Data Report NM-78-1, Water Year 1978, Water Resources Division, Albuquerque.

Bailey, P.C.E., P.I. Boon, D.W. Blinn and W.D. Williams. - 2006. Salinisation as an ecological perturbation to rivers, streams and wetlands of arid and semi-arid regions. In: R. Kingsford (ed.), Ecology of Desert Rivers, pp. 280-314. Cambridge University Press, New York.

Balon, E.K. - 1975. Reproductive guilds of fishes: a proposal and definition. J. Fish. Res. Board Can., 32: 821-864.

Bestgen, K.R. and S.P. Platania. - 1991. Status and conservation of the Rio Grande silvery minnow, Hybognathus amarus. Southwest. Nat., 36: 225-232.

Bestgen, K.R., B. Mefford, J. Bundy, C. Walford, B. Compton, S. Seal and T. Sorensen. - 2003. Swimming performance of Rio Grande silvery minnow. Colorado State University, Larval Fish Laboratory Contribution 132, U. S. Bureau of Reclamation, Albuquerque.

Bonner, T.H. and G.R. Wilde. - 2000. Changes in the Canadian River fish assemblage associated with reservoir construction. $J$. Freshw. Ecol., 15: 189-198.

Coombs, S.H. - 1981. A density-gradient column for determining the specific gravity of fish eggs, with particular reference to eggs of the mackerel Scomber scombrus. Mar. Biol. (N. Y.), 63: 101-106

Cowley, D.E. - 1979. Temporal and spatial distributions of fishes in the Black River, Eddy County, New Mexico. M.S. Thesis, Eastern New Mexico University, Portales.

Cowley, D.E. - 2003. Water requirements for endangered species - Rio Grande silvery minnow (Hybognathus amarus). 47th Annual New Mexico Water Conference, There's No Doubt We're in a Drought, WRRI Report No. 326: 97-107, http://wrri.nmsu. edu/publish/watcon/proc47/cowley.pdf (accessed 7 Nov 2008).

Cowley, D.E. -2006. Strategies for ecological restoration of the middle Rio Grande in New Mexico and recovery of the endangered Rio Grande silvery minnow. Rev. Fish. Sci., 14: 169-186.

Cowley, D.E. - 2008. Estimating habitat size for fish conservation in streams. Aquat. Conserv., 18: 418-431.

Cowley, D.E., P.D. Shirey, P. D. and M.D. Hatch. - 2006. Ecology of the Rio Grande silvery minnow (Hybognathus amarus) inferred from specimens collected in 1874. Rev. Fish. Sci., 14: 111-125.

Davin, W.T., C. Ethridge, C. Babb and S. Hileman. - 1999. Estimation of striped bass (Morone saxatilis) egg drift rate in the lower Savannah River. Final Report to the U. S. Army Corps of Engineers, Savannah District, December 1999.

Dudley, R.K. and S.P. Platania. - 1999. Imitating the physical properties of drifting semibuoyant fish (Cyprinidae) eggs with artificial eggs. J. Freshw. Ecol., 14: 423-430.

Dudley. R.K. and S.P. Platania. - 2007. Flow regulation and fragmentation imperil pelagic-spawning riverine fishes. Ecol. Appl., 17: 2074-2086.

Eaton, D.J. and J.M. Andersen. - 1987. The state of the Rio Grande: a study of water resource issues along the Texas/Mexico border. The University of Arizona Press, Tucson.

Edwards, R.J. and S. Contreras-Balderas. - 1991. Historical changes in the ichthyofauna of the lower Rio Grande (Rio Bravo del Norte), Texas and Mexico. Southwest. Nat., 36: 201-212.

Falconer, D.S. and T.F.C. Mackay. - 1996. Introduction to quantitative genetics, 4th ed. Pearson, Prentice Hall, UK.

Gallagher, R.P. and J.V. Conner. - 1983. Comparison of two ichthyoplankton sampling gears with notes on microdistribution of fish larvae in a large river. Trans. Am. Fish. Soc., 112: 280-285.

Gonzal, A.C., E.V. Aralar and J.M.F. Pavico. - 1987. The effects of water hardness on the hatching and viability of silver carp (Hypophthalmichthys molitrix) eggs. Aquaculture, 64: 111-118.

Goodnight, J.H. and W.R. Harvey. - 1978. Least squares means in the fixed effects general linear model. SAS Technical Report $R$-103. SAS Institute Inc., Cary, NC.

Hardy, J.D. Jr. - 1978. Development of fishes of the mid-Atlantic Bight: An atlas of the egg, larval, and juvenile stages. vol 3, 
Aphredoderidae through Rachycentridae. U.S. Fish and Wildlife Service Program FWS/OBS-78/12.

Härmä, M., A. Lappalainen and L. Urho. - 2008. Reproduction areas of roach (Rutilus rutilus) in the northern Baltic Sea: potential effects of climate change. Can. J. Fish. Aquat. Sci., 65: 2678-2688.

Harvey, B.C. - 1987. Susceptibility of young-of-the-year fishes to downstream displacement by flooding. Trans. Am. Fish. Soc., 116: 851-855.

Hedgecock, D. - 1994. Does variance in reproductive success limit effective population sizes of marine organisms? In: A.R. Beaumont (ed.), Genetics and evolution of aquatic organisms, pp. 122-134. Chapman and Hall, UK.

Hem, J.D. - 1970. Study and interpretation of the chemical characteristics of natural water, 2nd. Ed. Geological Survey WaterSupply Paper 1473.

Higgins, C.L. and G.R. Wilde. - 2005. The role of salinity in structuring fish assemblages in a prairie stream system. Hydrobiologia, 549: 197-203.

Hurley, N.M. - 1991. Transport simulation of striped bass eggs in the Congaree, Wateree, and Santee River, South Carolina. U.S. Geological Survey Water-Resources Investigations Rep., 91-4088.

Kehmeier, J., C.N. Medley and O.B. Myers. - 2004. Assessment of Pecos bluntnose shiner egg and larval drift potential in the Pecos River, New Mexico. Santa Fe: New Mexico Interstate Stream Commission.

Matthews, W.J. and E. Marsh-Matthews. - 2006. Persistence of fish species associations in pools of a small stream of the southern Great Plains. Copeia, 2006: 696-710.

Molokwu, C.N. and G.C. Okpokwasili. - 2002. Effect of water hardness on egg hatchability and larval viability of Clarias gariepinus. Aquac. Int., 10: 57-64.

Moore, G.A. - 1944. Notes on the early life-history of Notropis girardi. Copeia, 1944: 209-214.

North, E.W., R.R. Hood, S.R. Chao and L.P. Sanford. - 2005. The influence of episodic events on transport of striped bass eggs to an estuarine nursery area. Estuaries, 28: 106-121.

Platania, S.P. and C.S. Altenbach. - 1998. Reproductive strategies and egg types of seven Rio Grande Basin cyprinids. Copeia, 1998: 559-569.

SAS Institute, Inc. - 1989. SAS/STAT User's Guide, Version 6, Fourth Edition, Volume 2. Cary, NC.

Scheidegger, K.J. and M.B. Bain. - 1995. Larval fish distribution and microhabitat use in free-flowing and regulated rivers. $\mathrm{Co}$ peia, 1995: 125-135.

Scott, M.T. and L.A. Nielsen. - 1989. Young fish distribution in backwaters and main-channel borders of the Kanawha River, West Virginia. J. Fish Biol., 35(Suppl. A): 21-27.

Shirey, P.D. - 2004. Foraging habits and habitat utilization of Rio Grande silvery minnow (Hybognathus amarus) as inferred by diatom frustules. M.S. thesis, New Mexico State University, Las Cruces.

Shirey, P.D., D.E. Cowley and R. Sallenave. - 2008. Diatoms from gut contents of museum specimens of an endangered minnow suggest long-term ecological changes in the Rio Grande (USA). J. Paleolimnol., 40: 263-272.

Sidak, Z. - 1967. Rectangular confidence regions for the means of multivariate normal distributions. J. Am. Stat. Assoc., 62: 626-633.

Silva, L.V.F., B. Golombieski and B. Baldisserotto. - 2003. Incubation of silver catfish, Rhamdia quelen (Pimelodidae), eggs at different calcium and magnesium concentrations. Aquaculture, 228: $279-287$

Simon, T.P. - 1999. Assessment of Balon's reproductive guilds with application to midwestern North American freshwater fishes. In: T.P. Simon (ed.), Assessing the sustainability and biological integrity of water resources using fish communities, pp. 97-121. CRC Press LLC, Boca Raton.

Spade, S. and B. Bristow. - 1999. Effects of increasing water hardness on egg diameter and hatch rates of striped bass eggs. $N$. Am. J. Aquac., 61: 263-265.

Turner, T.F., M.J. Osborne, G.R. Moyer. M.A. Benavides and D. Alò. - 2006. Life history and environmental variation interact to determine effective population to census size ratio. Proc. $R$. Soc. B, 273: 3065-3073.

Van der Velden, J.A., F.A.T. Spannings, G. Flik and S.E.W. Bonga. - 1991. Early stages of carp (Cyprinus carpio) depend on ambient for their development. J. Exp. Biol., 158: 431-438.

Varsamos, S., C. Nebel and G. Charmantier. - 2005. Ontogeny of osmoregulation in postembryonic fish: a review. Comp. Biochem. Physiol. A Comp. Physiol., 141: 401-429.

Welker, T.L. and D.L. Scarnecchia. - 2004. Habitat use and population structure of four native minnows (family Cyprinidae) in the upper Missouri and lower Yellowstone rivers, North Dakota (USA). Ecol. Freshw. Fish, 13: 8-22.

Winston, M. R, C.M. Taylor and J. Pigg. - 1991. Upstream extirpation of four minnow species due to damming of a prairie stream. Trans. Am. Fish. Soc., 120: 98-105.

Yeh, G.T. and C.F. Yeh. - 1980. Mathematical modeling of the distribution of fish eggs from spawning regions of a river. Ecol. Model., 8: 97-107.

Received November 15, 2008. Accepted June 25, 2009.

Published online October 5, 2009. 